\title{
The representation of colonial discourse in Indonesian secondary education history textbooks during and after the New Order (1975-2013)
}

\section{Hieronymus Purwanta}

To cite this article: Hieronymus Purwanta (2018) The representation of colonial discourse in Indonesian secondary education history textbooks during and after the New Order (1975-2013), History of Education, 47:3, 349-361, DOI: 10.1080/0046760X.2017.1384855

To link to this article: https://doi.org/10.1080/0046760X.2017.1384855

曲 Published online: 23 Oct 2017.

Submit your article to this journal $\widetilde{ }$

Џ Article views: 88

Q View related articles $\sqsubset$

View Crossmark data \lceil 


\title{
The representation of colonial discourse in Indonesian secondary education history textbooks during and after the New Order (1975-2013)
}

\author{
Hieronymus Purwanta \\ Department of History Education, Faculty of Teacher Training and Education, Sanata Dharma University, \\ Yogyakarta, Indonesia
}

\begin{abstract}
This study aimed to analyse the text and context of history textbooks that established Dutch colonialism as a determinant factor in the New Order era and later. Two research questions were postulated: (1) Why was the discourse of colonisation maintained in textbooks after the proclamation of independence in 1945? (2) How was the colonial discourse represented in secondary education history textbooks from the six national curriculum reforms? To answer these questions, this study analysed secondary education history textbooks used during five periods of different national curricula from 1975 to 2013. The analysis was conducted using Teun A. van Dijk's Critical Discourse Analysis (CDA). The results show that modern professional historians were the producers of the colonial discourse that was reproduced by the textbook writers. These historians established western culture as the ideal model of sociocultural life and constructed Indonesian history as a westernisation process using Dutch colonialism as a determinant factor. Indonesians were narrated into being passive objects.
\end{abstract}

\section{ARTICLE HISTORY}

Received 22 September 2016 Accepted 22 September 2017

\section{KEYWORDS}

Determinant factor; Dutch colonialism; history textbooks; Indonesia; modern professional historians; westernisation

\section{Introduction}

Indonesia was first colonised by the Dutch from 1800 to 1942 and then by Japan during the Second World War (1942-1945). The long experience of being colonised resulted in sceptical feelings towards westerners, both psychological and philosophical. This attitude appeared when Indonesia faced the cold war between the Western Bloc (the United States and Western European countries) and the Eastern Bloc (Soviet and Eastern European countries). Although not considered part of either of those blocs, Indonesia preferred to have a closer relationship with the Eastern Bloc countries. Even at the end of the 1950s, Indonesia appeared to be anti-western and considered the Allies to be imperialists who should be fought. ${ }^{1}$

This anti-western discourse also appeared throughout Indonesian historiography. At the First National Seminar in Yogyakarta in 1957, the Minister of Education, Muhammad

CONTACT Hieronymus Purwanta hpurwanta@usd.ac.id

${ }^{1}$ Franklin B. Weinstein, Indonesian Foreign Policy and the Dilemma of Dependence: From Sukarno to Soeharto (Jakarta: Equinox Publishing, 2007), 19. 
Yamin, said that the national history of Indonesia should be written from a nationalist perspective to help promote the spirit of nationalism and preserve national unity. This statement reflected the fact that Indonesia was a new nation and needed to make its people proud to be Indonesians. On the opposing side, Soedjatmoko warned about the danger of using history to boost nationalism. ${ }^{2}$ In his opinion, history, like science, should be non-partisan and free from political interests. These conflicting opinions endured and have always coloured the development of Indonesian historiography. ${ }^{3}$

On 1 October 1965, a group of President Sukarno's palace guard, led by Lieutenant Colonel Untung Syamsuri, kidnapped and murdered seven high-ranking army generals. ${ }^{4}$ The victims included Ahmad Yani, who had been nominated personally by President Sukarno to replace him as the president of the Republic of Indonesia. The murders demonstrated a political crisis that culminated in a national leadership transfer amounting to a military coup. Suharto became the president in 1967 and began a military regime that was known as Orde Baru (the New Order). ${ }^{5}$

In opposition to the previous era, Suharto adopted an anti-Eastern policy and allied Indonesia with the Western Bloc. He prohibited communism, socialism and Marxism from being developed in Indonesia and killed hundreds of thousands of members and sympathisers of the Partai Komunis Indonesia/PKI (Indonesian Communism Party). ${ }^{6}$ In addition to these dictatorial actions, the New Order also formed a partnership with western countries that provided guidance and incentives, such as loan providers and investors in Indonesian development programmes. ${ }^{7}$ Because of its affiliation with Western Bloc countries, Indonesia became the investment destination for many of those western countries, especially in the field of mining. For example, the Intergovernmental Group on Indonesia (IGGI) was formed in September 1966. This organisation consisted of creditor countries acting as an international finance association whose primary responsibility was giving credit to the development programmes of Indonesia. ${ }^{8}$

The intimate relation between Indonesia and the West resulted in the need to rewrite Indonesian history, including the textbooks for history lessons. This requirement was accomplished through the Second National History Seminar, held in Yogyakarta in 1970. One of the results of the seminar was the establishment of a committee of national history writing with Sartono Kartodirdjo as the chairman of the team. The national history of Indonesia was not only planned as a standard book at the university level but also as a

${ }^{2}$ Soedjatmoko, 'The Indonesian Historian and His Time', in An Introduction to Indonesian Historiography, ed. Soedjatmoko (Jakarta: PT Equinox Publishing Indonesia, 2006), 404-15.

${ }^{3}$ Rommel Curamming,'Towards Reinventing Indonesian Nationalist Historiography', Kyoto Review of Southeast Asia 3. Nations and Other Stories. March 2003, https://kyotoreview.org/issue-3-nations-and-stories/an-introduction-to-indonesian-historiography/ (accessed August 21, 2017)

${ }^{4}$ Andrew Lim, 'A Tale of Two Narratives: The New Zealand Print Media and Indonesian-Malaysian Confrontation, 1963-1966', New Zealand Journal of Asian Studies 18, no. 1 (2016): 46.

${ }^{5}$ Michael R. J. Vatikiotis, Indonesian Politics Under Suharto: The Rise and Fall of the New Order (London: Taylor \& Francis, 1998), 20-4.

6John Roosa, Pretext for Mass Murder: The September 30th Movement and Suharto's Coup d'État in Indonesia (Wisconsin: University of Wisconsin Press, 2006), 21-7.

${ }^{7}$ Eva Riesenhuber, The International Monetary Fund Under Constraint: Legitimacy of Its Crisis Management (The Hague: Kluwe Law International, 2001), 139.

${ }^{8}$ Sadiq Ahmed, 'Indonesia: Stablisation and Structural Change', in Restructuring Economies in Distress: Policy Reform and the World Bank, ed. Vinod Thomas, Ajay Chhibber, Mansoor Dailami and Jaime de Melo (New York: Oxford University Press, 1995), 378-9. 
main reference textbook for school students. ${ }^{9}$ The new history textbook for the secondary level was first launched in support of the implementation of the 1975 national curriculum.

The new history textbook had a different tone that was the more positive towards the position of the West in general and Dutch colonialism in particular. Earlier textbooks had depicted Dutch colonial rule as cruel and oppressive. They described the various types of suffering that Dutch colonialism brought to the Indonesian people, such as the seizure of indigenous farmlands, which caused some farmers to fall into cheap wage labour. ${ }^{10}$ However, the new history textbooks introduced for the 1975 curriculum positioned Dutch colonialism as the determinant factor of many historical events in Indonesia, including the end of feudalism and the birth of Indonesian nationalism. Therefore, the colonial period was described as the westernisation process of Indonesians that transformed them into a westernised society. ${ }^{11}$

One impact of using the new history textbooks in the teaching and learning process is the birth of a new generation that lacks an Indonesian identity. Borrowing Nordholt's view, Indonesian history was depicted in these new textbooks as a history without people, resulting in the emergence of people without a history. ${ }^{12}$ The logical consequence of this point of view is a young Indonesian generation infected by xenocentrism. This generation views their own indigenous culture as old-fashioned and out of date while appreciating elements of foreign culture as ideal. For example, research exploring the musical orientation of young Indonesians revealed that young Indonesians enjoy western music (the US and Western Europe) better and assume that local music is old-fashioned. ${ }^{13}$ This negative point of view also expands beyond music. A survey of university students in Jakarta revealed that the students tended to have negative opinions of Indonesians, such as considering them to be lazy and corrupt. ${ }^{14}$ For them, Indonesia is little more than geographical facts and the place where they were born and lived. ${ }^{15}$

In light of the above background, this study aimed to answer the following questions:

(1) Why was the discourse of colonisation maintained in textbooks after the proclamation of independence in 1945 ?

(2) How was the colonial discourse represented in secondary education history textbooks from the six national curriculum reforms?

\section{Methodology}

This study employed secondary education history textbooks that were used during the New Order (1967-1998) and the Reformation era (1998-present). During the New Order, the national curriculum was renewed in 1975, 1984 and 1994. After the New Order collapsed

\footnotetext{
${ }^{9}$ Michael Kuhn and Doris Weidemann, eds., Internationalisation of the Social Sciences: Asia - Latin America - Middle East - Africa - Eurasia (Wetzlar: Bielefeld, 2010), 118-119.

${ }^{10}$ Sanusi Pane, Sedjarah Indonesia, vol. 2 (Jakarta: Departemen Pemuda, Pendidikan dan Kebudayaan, 1956), $220-221$.

${ }^{11}$ Nugroho Notosusanto and Yusmar Basri, eds., Sejarah Nasional Indonesia Untuk SMA (The national history of Indonesia for secondary school), vol. 3 (official textbook) (Jakarta: Departemen Pendidikan dan Kebudayaan, 1981), 13-28.

${ }^{12} \mathrm{Henk}$ Schulte Nordholt, 'De-colonising Indonesian Historiography', paper delivered at the Centre for East and South-East Asian Studies public lecture series 'Focus Asia', May 25-27, 2004 (Sweden: Lund University, 2005), 11.

${ }^{13}$ Jeremy Wallach, 'Exploring Class, Nation and Xenocentrism in Indonesian Cassete Retail Outlet', Indonesia 74 (2002): 79-102.

${ }^{14} \mathrm{~A}$. Malik Gismar, 'Mencari Indonesia', in Reinventing Indonesia:Menemukan Kembali Masa Depan Bangsa, ed. Komarudin Hidayat dan Putut Wijanarko (Jakarta: Mizan, 2008), 205.

15 Jakarta Post, August 16, 2002.
} 
in 1998, the Department of Education (DoE) made a revision to the 1994 curriculum in 1999, which focused on eliminating the description of the development programmes of the New Order. In the Reformation era, the DoE has renewed the national curriculum twice: in 2006 and 2013. For each period in which a new curriculum was implemented, textbooks were introduced that were 'considered indispensable and which were required for high school students wishing to learn authoritatively about Indonesian history'. ${ }^{16}$ For those reasons, this research focused on five history textbooks that were widely required in secondary schools during the New Order period. In the Reformation era, the production of history textbooks for the 2006 curriculum was the responsibility of the Badan Standar Nasional Pendidikan (Board of National Standard of Education). The board selected and published textbooks that were then produced as electronic books (e-books). Teachers and students can download these textbooks free of charge at http://bse.kemdikbud.go.id/. The secondary history textbook selected for social studies was Sejarah untuk SMA (History for Secondary School), written by Tarunasena. For the 2013 curriculum, the system of production for the secondary history textbook changed, and the DoE established a team consisting of professional historians to write the textbook.

In accordance with the recommendation of UNESCO, this study adopted a hermeneutic approach. ${ }^{17}$ To address the aforementioned problems, high school history textbooks were viewed as historical documents that contain 'the expression of subjective past humans about their lives as manifested through text or writing' and particularly the production and reproduction of discourse. ${ }^{18}$ By viewing explanations in school textbooks as 'the subjective expression' of subjects who have power and interests, text analysis can not only surpass the grammatical meaning but also more deeply explore the contextual meaning in order to understand the assumptions, ideology and messages that are discussed and presented in the textbooks and delivered to students as audience. ${ }^{19}$ These assumptions, ideologies and discourse messages come in various forms of syntax; they can be terms, sentences or phrases. ${ }^{20}$

To analyse the content of these history textbooks, this study used Critical Discourse Analysis (CDA), which was developed by Teun A. van Dijk and covers three levels, namely, macrostructure, superstructure and microstructure. ${ }^{21}$ Discourse representation in the history textbooks could be deconstructed by analysing the binary oppositions that they use. These oppositions are not a simple series of contradictions; they contain one term that is viewed as being superior and another term viewed as negative or inferior. ${ }^{22}$ Superior terms refer to the choice of words and other linguistic explorations that the textbooks writers used in depicting something positively or in favouring certain situations, individuals or behaviours. From this viewpoint, superior terms mark the presence of and describe the 'interest groups' (self). ${ }^{23}$ Conversely, inferior terms are contextually used to negate the other persons and

\footnotetext{
${ }^{16}$ Simon Philpott, Rethinking Indonesia: Postcolonial Theory, Authoritarianism and Identity (Basingstoke: Palgrave Macmillan, 2000), 51.

${ }^{17}$ Falk Pingel, UNESCO Guidebook on Textbook Research and Textbook Revision, 2nd revised and updated ed. (Paris: UNESCO, 2010), 68.

${ }^{18}$ Ruth Wodak and Michael Meyer, eds., Methods of Critical Discourse Analysis (London: Sage, 2006), 71-2.

${ }^{19}$ Keith Crawford, 'Constructing National Memory: The 1940/41 Blitz in British History Textbooks', in Internationale Schulbuchforschung, vol. 23 (Hannover: Verlag Hahnsche Buchhandlung, 2001), 327.

${ }^{20}$ Teun A. van Dijk, Ideology and Discourse: A Multidisciplinary Introduction (Barcelona: Pompeu Fabra University, 2000$), 4$.

${ }^{21}$ Teun A. van Dijk, Macrostructures: An Interdisciplinary Study of Global Structures in Discourse, Interaction, and Cognition (Mahwah, NJ: Erlbaum 1980), 10.

22Julie Rivkin and Michael Ryan, Literary Theory: An Anthology (Chichester: Wiley, 2017), 1590.

23 Jacques Derrida, Of Grammatology, trans. Gayatri Chakravorty Spivak (London: Johns Hopkins University Press, 1997$), 12$.
} 
interest groups who are not seen or described in the same manner. Negation can be an expression of the excluding, ignoring, demeaning, blaming, villainising or sacrificing of an individual, group or idea of 'the others' who do not match the interests of the ruling group. ${ }^{24}$

\section{Role of modern professional historians}

The colonial discourse was fabricated by local historians, known as modern professional historians (MPHs). ${ }^{25}$ In this context, these professional historians were historians who graduated from a university. Most of them graduated in the last decade of the Sukarno government and during the New Order era. MPHs' historical construction was characterised by a grand narrative that revealed history as the progress which culminated in the glory of the modernity of the nation-state. ${ }^{26}$

This grand narrative implicitly represented the re-colonisation of western political cultures in Indonesia, because modernity as a way of life and as the process of material changes, which are characterised by technological innovation and management, was pioneered by western society. ${ }^{27}$ The MPHs' grand narrative was teleological in the sense that all sociocultural dynamics, including historical events, are directed to a single goal, that is, the development of Indonesia from a traditional to a modern society. ${ }^{28}$ This point of view was in line with the economic theory that developed in the 1960s, which explained that the entire society would develop in steps from a traditional community to the age of high mass consumption. ${ }^{29}$

The MPHs possessed a modernistic point of view that intellectuals who received a western education and thought and acted like a westerner were the pioneers of the Indonesian national movement. These intellectuals were the social groups in Indonesia who were considered by MPHs to be educated, working based on their skills, open minded, highly sensitive, and the founders of modern organisations; they were also seen as having the national vision to advance national unity and integrity. Thus, their movement covered the entire nation, and this group of intellectuals was known as the national elite. ${ }^{30}$

To strengthen the argument that the group who experienced western education included the best historical actors, the narrative in contemporary textbooks also negated Indonesian noblemen. These narratives presented noblemen who kept Indonesian culture alive as regionally oriented, traditional and only having hereditary jobs. In a textbook written by Moedjanto, this class was labelled 'the architect of misery'. ${ }^{31}$ The positioning of western culture and Indonesian culture in binary opposition was not new, as Eykman and Stapel had established this view in 1941 by stating that the power of the Netherlands (in Indonesia)

\footnotetext{
${ }^{24}$ Teun A. van Dijk, 'Discourse Analysis as Ideology Analysis', in Language \& Peace, ed. Christina Schäffne and Anita L. Wenden (London: Taylor \& Francis e-library, 2005), 22.

${ }^{25}$ Indonesia has historical accounts written by non-professional historians, called amateur historians. See Sony Karsono, Setting History Straight? Indonesian Historiography in the New Order (thesis, Department of Southeast Asian studies and the Center for International Studies) (Ohio: Ohio University, 2005), 194.

${ }^{26}$ Heather Sutherland, 'Meneliti Sejarah Penulisan Sejarah', in Bambang Purwanto dan Ratna Saptari, PerspektifBaru Penulisan Sejarah Indonesia, ed. Henk Schulte Nordholt (Jakarta: Yayasan Obor Indonesia, 2008), 34-5.

${ }^{27}$ Ibid., 34.

${ }^{28}$ bid., 35.

${ }^{29}$ Walt Whitman Rostow, The Stages of Economic Growth: A Non-Communist Manifesto, 3rd ed. (Cambridge: Cambridge University Press, 1990), 4-16.

${ }^{30}$ Notosusanto and Basri, eds., Sejarah Nasional Indonesia Untuk SMA, $21-2$.

${ }^{31}$ Gregorius Moedjanto, Nani Sunarti, Chr. Kristanto Dh., Anton Haryono and A. A. Padi, Sejarah Nasional Indonesia (National history of Indonesia for high school), vol. 2 (Jakarta: Gramedia Widiasarana, 1992), 11.
} 
especially benefited the local people. These scholars noted that before the enforcement of Dutch power, the people were treated badly by their local leaders (the kings). However, the Dutch government then guaranteed the safety of the Indonesian people and took their welfare into consideration. The model in Eykman and Stapel's writing is referred to in Indonesian historiography as colonial centrist, viewing the colonist as central. ${ }^{32}$

The construction of the history of modern Indonesia as a westernisation process has historically been considered the result of studies by western historians who were cited by Indonesian historians. One of these western studies was Robert van Niel's The Emergence of the Modern Indonesian Elite, which was published in 1960 and was translated into Indonesian in 1984. The thesis offered by Niel stated that all modern Indonesian elites were the result of western education and had adopted at least some western cultural aspects. These elites were described as 'more Western in education and teaching and in the conception of nation and community. ${ }^{33}$

In Niel's work, Snouck Hurgronje is honoured as the central actor at the beginning of the westernisation process in Indonesia. The book explains that shortly after Snouck Hurgronje's arrival in the Netherlands Indies in 1889, he turned to Raden Bagus Djajawinata (1854-1899), Regent (Bupati) of Serang from 1894 to 1899 and Aboe Bakar Djajadiningrat's elder brother, in Banten, West Java, and took charge of the education of his sons Achmad, Hoesein and Hasan Djajadiningrat. All three children would attend the HBS (Hoogere Burger school/Secondary School). Of those, Achmad was the very first Indonesian boy to come under the guidance of Snouck Hurgronje. Achmad was Hurgronje's 'initial experiment' (Eerste proefneming), as Achmad Djajadiningrat himself wrote, copying the terminology of his mentor. Snouck Hurgronje took Achmad under his wing in 1890, when he was about 13 years old. ${ }^{34}$

One Indonesian historian who followed Robert van Niel's ideas and became an influential leader of the MPHs was Sartono Kartodirdjo. He was the key editor in the writing of the National History of Indonesia (published in 1975) and was aided by Marwati Djoened Poesponegoro and Nugroho Notosusanto. Kartodirdjo is also the person who introduced the social science approach as the characteristic of the professional historian, using social sciences theories and concepts in an interdisciplinary analysis of historical events. By contrast, historians who reconstructed history using a descriptive-narrative model were negated by being labelled amateur historians. ${ }^{35}$

From his point of view, Kartodirdjo stated that the Dutch Ethical Policy was a colonial policy that brought Indonesia as a colony into the orbit of the culture of the Netherlands as the mother country. This policy made Indonesian people absorb the system of western culture. ${ }^{36}$ The result of the Ethical Policy was the emergence of a new social class, called intellectuals, who thought and lived in a western manner. These intellectuals are described as a social class who were impressed by the development occurring in western countries and inspired to modernise Indonesia based on a western model, specifically the Netherlands. ${ }^{37}$

\footnotetext{
${ }^{32}$ R. Mohammad Ali, Pengantar Ilmu Sejarah Indonesia (Yogyakarta: LKIS, 2005), 150.

${ }^{33}$ Robert van Niel, Munculnya Elite Modern Indonesia, trans. Zahara Deliar Noer, 2nd ed. (Jakarta: Pustaka Jaya, 2009$), 43$.

${ }^{34}$ Kees van Dijk. 'Elitist Premises of Snouck Hurgronje's Association Fantasy', Studia Islamika: Indonesian Journal for Islamic Study 17, no. 3 (2010): 419.

${ }^{35}$ Sartono Kartodirdjo, Pendekatan Ilmu Sosial dalam Metodologi Sejarah (Jakarta: Gramedia, 1992), 1-2.

${ }^{36}$ Sartono Kartodirdjo, Pengantar Sejarah Indonesia Baru: Sejarah Pergerakan Nasional, vol. 2 (Jakarta: Gramedia,1992), 50.

${ }^{37}$ Ibid., 84.
} 
In addition to focusing on the westernisation process, the representation of colonial discourse was expressed by negating indigenous culture, which it was considered appropriate to abandon. This negation was accomplished by constructing an explanation that the indigenous culture had been destroyed in the westernisation process. Furthermore, Kartodirdjo explained that the unavoidable penetration of the Dutch colonial system into Indonesia caused indigenous culture and customs to fracture, ultimately resulting in a crisis. The power of the new socioeconomic system created a new way of life that people had to face. Many life values were shaken and their relevance questioned in respect of the new condition. Many traditional symbols lost their meaning as this change reached the foundations of Indonesian culture. ${ }^{38}$

\section{Dutch colonialism as the determinant factor}

The representation of colonial discourse in history textbooks was pioneered by Nugroho Notosusanto and Yusmar Basri through Sejarah Nasional Indonesia Untuk SMA (National History of Indonesia for High School) for the 1975 curriculum. ${ }^{39}$ This textbook was used as the main reference for history textbooks that were published later. The textbook for the 1984 curriculum even had the exact same titles for its chapters and subchapters as the previous textbook.

In the textbook for the 1975 curriculum, the colonial discourse was represented by establishing Dutch colonialism as the determinant power. Determinant in this study is an element that decisively affects the nature or outcome of something. From the principle of causality perspective, the element is viewed as the only one that caused many historical events to happen. One historical event that was widely discussed in this textbook as a determinant factor is the Ethical Policy. The Policy was a course of action at the turn of the twentieth century aimed at the effective Dutch occupation of the whole Indonesian archipelago both economically and politically. ${ }^{40}$ The Policy had three main programmes: irrigation, transmigration and education used to support the occupation. ${ }^{41}$ However, the textbook presented the policy as positive and explained that Dutch colonialism had built large plantations in rural areas of the Indonesian archipelago with Java as its centre. The development of plantations and factories led to the expansion of agriculture and irrigation, the differentiation of labour, the appearance and expansion of a monetary economic system, and the growth of small industries. ${ }^{42}$ In a textbook for the 1984 curriculum, the influences of the Dutch colonial policies were explained in detail. The textbook stated that the emergence of urbanisation and transmigration became the basis for the growth of nationalism. The large cities in Java were finally marked by the multi-ethnic life of the bumiputera (indigenous people), who faced the same struggles. These big cities were not only economically functional for migrants, but unintentionally functioned as social and political education centres. ${ }^{43}$

\footnotetext{
${ }^{38}$ Ibid., 99-100.

${ }^{39}$ Nugroho Notosusanto and Yusmar Basri are key figures in the Department of Education and Culture project referred to as high school history textbooks research. See Katharine E. McGregor, History in Uniform: Military Ideology and the Construction of Indonesia's Past (Singapore: National University of Singapore, 2007), 153.

${ }^{40}$ Willem Otterspeer, 'The Ethical Imperative', in Leiden Oriental Connection 1850-1940, ed. Willem Otterspeer (Leiden: E. J. Brill, 1989), 204.

${ }^{41}$ M. C. Ricklefs, A History of Modern Indonesia since c.1200, 3rd ed. (Houndmills: Palgrave, 2001), 194.

${ }^{42}$ Notosusanto and Basri, eds., Sejarah Nasional Indonesia Untuk SMA, 14-16.

${ }^{43}$ Moedjanto, et al., Sejarah Nasional, 4-5.
} 
In textbooks for the 1994 curriculum, the position of the determinant factor was widened to include not only Dutch colonialism but also western culture in general. A new chapter was added called 'Perkembangan Kolonialisme dan Imperialisme Eropa dalam Politik, Ekonomi dan Ideologi' (The growth of European colonialism and imperialism in politics, economics, and ideologies). This chapter explained the development of various philosophical theories such as liberalism, socialism, nationalism and democracy. ${ }^{44}$ When describing the strength of Dutch colonialism as the determinant, the positive influences of the economic policy of the colonial government were described in greater detail. They included the construction of the railroads and the birth of a new middle class consisting of the native Dutch, the Indo-Dutch, some indigenous (Indonesian) people, and the Chinese. ${ }^{45}$ The textbook also gave honourable position to the liberal group of businessmen who opposed the corvee, or forced labour system, because that system was seen as reducing the existential freedom of human beings. Finally, the textbook stated that modern businessmen struggled to ensure that all workers received an appropriate salary. ${ }^{46}$

Sardiman and Kusriyantinah's textbook goes further and represents colonial discourse in one volume. ${ }^{47}$ To show the significant role of western culture, the textbook explained the roots of western colonisation, such as the end of the Dark Ages in Europe, the Renaissance, the Enlightenment, the Industrial Revolution, and overseas expeditions. In addition to describing the history of Europe, the textbook also explained the emergence of many western ideologies, i.e. nationalism, liberalism, socialism and democracy. The position of Indonesia was explained at the end of every chapter as a response to the stimulus of colonial policies.

In the next volume, Sardiman and Kusriyantinah's textbook focuses on the emergence and development of Indonesian national movements. Like other textbooks, colonial discourse is presented through the narrative of the implementation of the Ethical Policy as determinant factor for the emergence of national consciousness. ${ }^{48}$ The textbook also offers more descriptions of the overseas Indonesian student movement in the Netherlands than other organisations. The textbook spent only five pages explaining the most important organisation among Indonesian movements, Partai Nasional Indonesia (the Indonesian National Party). However, when presenting Perhimpunan Indonesia (the Association of Indonesia) in the Netherlands, the textbook used 11 pages. From this viewpoint, the textbook wanted to present the Association of Indonesia in the Netherlands as more important than the Indonesian National Party.

With the collapse of the New Order in 1998 and the emergence of the Reformation era, the 1994 curriculum was revised. Because the New Order was viewed as having failed politically at implementing development programmes, the content of those programmes was abandoned. As a result, a new chapter was added entitled 'Pengaruh Paham Baru dan Peristiwa Penting Dunia Terhadap Perjuangan Kemerdekaan Indonesia' (The impacts of western ideologies and important international events in the Indonesian struggle for

\footnotetext{
${ }^{44}$ I Wayan Badrika, Sejarah Nasional Indonesia dan Umum untuk SMA (National history of Indonesia and the world for high school) vol. 2 (Jakarta: Erlangga, 1997).

${ }^{45}$ Ibid., 161.

${ }^{46}$ Ibid., 160.

${ }^{47}$ Sardiman A. M. and Kusriyantinah, Sejarah Nasional dan Umum untuk SMA (National history of Indonesia and the world), vol. 2a (Surabaya: Kendang Sari, 1996).

${ }^{48}$ Ibid., vol. $2 b, 11$.
} 
independence).$^{49}$ In addition to explaining the growth of ideologies in Europe, the new chapter focused on discussing the growth of nationalism in Asia and Africa, such as the rise of nationalism in Japan, China, India, Turkey and Egypt. From this viewpoint, the author seemed to reinforce the thesis that the emergence of a national movement in Indonesia was a mere result of developments that occurred beyond Indonesians, i.e. Dutch colonialism, European ideologies, or Asian and African nationalism.

In 2006, the Ministry of Education launched a new national curriculum that led to the competency-based curriculum..$^{50}$ However, this curriculum did not demonstrate much change in the patterns of historical explanation that had been present in secondary school textbooks when compared with the previous curriculum, which had been a material-based curriculum. The most striking difference was seen in the level of depth of explanations. In textbooks for the 2006 curriculum, Dutch colonial policies from the nineteenth century up to the mid-twentieth century were described in only eight pages. ${ }^{51}$ The discourse of Dutch colonialism as a determinant factor was shown more in physical developments, such as the network of highways and railways. ${ }^{52}$

In the history textbooks for the 2013 curriculum, the narrative of the role of Dutch colonialism as a determinant factor was decreased, especially when addressing economic policy. Dutch colonialism was portrayed as applying economic policy that is/was based on a system of western capitalism through commercialisation, monetary systems and commodities. This system was supported by a policy of taxation on land, plantation systems, banking, industry, trade and shipping. ${ }^{53}$ The use of 'western capitalism' indicates that the textbook's author looked at Dutch colonialism as merely money-oriented. In supporting this discourse, the textbook explained that the Indonesian people had suffered. ${ }^{54}$

Unlike the discourse concerning economics, the narrative of educational development is relatively varied among the different periods of the curriculum. The history textbooks from 1975 and 1984 describe educational development with details such as the various types of schools: Volksschool (rural school), Hollands Inlandse School (elementary), Middle Meer Lager Onderwijs (primary), and Algemene Middelbare School (secondary). In addition, the colonial government was also deemed meritorious because it developed vocational schools such as Opleiding School Voor Inlandsche Ambtenaren (the School of Civil Service for Indonesians), Kweekschool (the School for Teachers), and Technische Hooge School (the School of Engineering). ${ }^{55}$ The curricula of both years emphasised educational development as the most important determinant factor for the emergence of Indonesian nationalism. Moedjanto shows the important role of educational policy with an analogy that Dutch colonialism 'dug its own grave' because it brought its power to an end through its own educational policy. ${ }^{56}$

\footnotetext{
${ }^{49}$ Siti Waridah Q., Sukardi and Sunarto, Sejarah Nasional dan Umum untuk SMA (National history of Indonesia and the World), vol. 2, Chapter 2 (Jakarta: Bumi Aksara, 2000), 36.

${ }^{50}$ The Competency-Based Curriculum (CBC) is designed to develop students'skills based on four UNESCO principles: learning to know, to do, to be, and to live together. The Indonesian Department of Education added a special competence called 'learning to believe in the Almighty God'. See Badan Standard Nasional Pendidikan (BSNP/Board of National Education Standards), Panduan Penyusunan Kurikulum Tingkat Satuan Pendidikan (Jakarta: BSNP, 2006), 3-4.

${ }^{51}$ Tarunasena Mamoer, Sejarah untuk SMA (History for high school), vol. 2 (Bandung: Armico, 2009), 182-90.

52|bid., 189.

${ }^{53}$ Sardiman A.M. and Amurwani Dwi Lestariningsih, Sejarah Indonesia (History of Indonesia), vol. 4 (Jakarta: Departemen Pendidikan dan Kebudayaan, 2014), 145.

${ }^{55}$ Notosusanto and Basri, eds., Sejarah Nasional Indonesia, 22-5.

${ }^{56}$ Moedjanto et al., Sejarah Nasional, 5.
} 
To reinforce the thesis that western education was a determinant factor, both textbooks negated Indonesia's traditional elite. These elites were described as the descendants of noble or royal families who held hereditary power. The two textbooks favoured the national elites who were western educated as a new social class of advanced thought.

In the history textbooks for the 1994 curriculum, an explanation of Dutch colonial policies in the education field occupies only a small portion (just one page) and was described in one paragraph. Nevertheless, the positioning of educational development as a determinant factor is relatively strong. Western education was depicted as the factor that improved the abilities of Indonesian youth when comparing the condition of Indonesia with the West. The consciousness of a national movement arose out of that comparison. ${ }^{57}$ From this viewpoint, the reduction in the number of words in the textbooks indicated that the position of Dutch colonialism as a determinant factor did not disappear. The central position of western culture was represented by explaining the important role of the people who studied in the Netherlands in determining the direction of development of the national movement in Indonesia. The textbook described in detail the founding of the Association of Indonesia, its development from a social to a political organisation, and its role in building Partai Nasional Indonesia Baru (PNIB/the New Indonesian National Party). ${ }^{58}$

In the 2006 curriculum, the history textbook discussed education in greater depth than the 1994 curriculum had. It explained that western education in Indonesia was able to grow rapidly due to the active involvement of religious organisations, namely Zending (the mission of the Protestants) and Missionaris (the mission of the Catholics). These groups spread their religions by developing schools in the various islands, such as Maluku, North Sulawesi, East Nusa Tenggara, Java, Batavia, Halmahera, Buru, Irian, Poso, Tapanuli (Sumatra), and Southeast Sulawesi. ${ }^{59}$ In addition to explaining the positive impacts of education in supporting Indonesian movements towards independence, the textbook also criticised the high level of discrimination in the education system developed by Dutch colonialism. Dutch colonialism was described as distinguishing between the schools for westerners/Europeans and those for the indigenous people. Education for indigenous people was divided into two types, namely schools for the nobility and schools for the common people. ${ }^{60}$

In the history textbooks of the 2013 curriculum, the narrative was short and focused on education as a determinant factor in the birth of a new class called the national elites. They had the role of developing unity between ethnic groups and struggled to liberate the nation of Indonesia from every form of Dutch colonial oppression. ${ }^{61}$ As in the history textbook for the 1994 curriculum, the textbook for the 2013 curriculum gave more attention to the existing Association of Indonesia in the Netherlands. The descriptions included the development of the Association from its founding under the name Indische Vereniging in 1908 to its transformation into a political organisation. ${ }^{62}$

\footnotetext{
${ }^{57}$ Siti Waridah Q. et al., Sejarah Nasional dan Umum untuk SMA, 120.

${ }^{58}$ I Wayan Badrika, Sejarah Nasional Indonesia dan Umum untuk SMA, 218-28.

${ }^{59}$ Tarunasena M., Sejarah untuk SMA, 190-2.

${ }^{60} /$ bid., 192.

${ }^{61}$ Sardiman A.M. and Amurwani Dwi Lestariningsih, Sejarah Indonesia, 146.

${ }^{62}$ Ibid., 176-8.
} 


\section{Discussion}

Discourse production and reproduction through history textbooks to fit in with the national interests happen in many countries. In Southeast Asia, Indonesia and Malaysia share many similarities in religion and ethnic roots of their population majority, in their experiences of being colonised, and in their economics, which are controlled and dominated by the Chinese ethnic group. However, they were very different in constructing and narrating their past. Research showed that Malaysia is more concerned in establishing unity among its three main ethnic populations: Malay, Indian and Chinese. ${ }^{63}$ The domination of the Chinese in economics is viewed by the government as the major aspect of national disunity. Ethnic conflict between Malay and Chinese, which grew with its climax in the communal riots that took place on 13 May 1969, was viewed as very dangerous for the existence of Malaysia as a nation-state. ${ }^{64}$

To produce unity, there is a belief among national leaders that the government has to create a programme to protect Malays by eradicating income inequalities and through redistribution of wealth. In 1970 the government launched policies in national economics, national language, national culture and national education based on Malay interests. In the line of national policy in education, the grand narratives of history textbooks were constructed to build the Malay culture and the Islamic value system as the basis of national identity and nationhood. ${ }^{65}$ The Malay ethnic group in the country is treated as bumiputera (son of the soil/indigenous), which has special rights that are mentioned in the Malaysian Constitution. On the other hand, Chinese and Indians are labelled as immigrants. Therefore, the narrative of history textbooks suggested that Indian and Chinese ethnic groups had to naturalise themselves in Malaysian culture. ${ }^{66}$ Kheng criticised the history textbook policy as the representation of 'insecurity and fear among Malays that Chinese would overtake them in open competition'. ${ }^{67}$

Similar discourse production to that of Indonesia is found in the narrative of Ghana's history textbooks. Ghana's elites view their nation as an underdeveloped country that must transform itself into a modern state where

the national economy is managed in such a manner as to maximize the rate of economic development and to secure the maximum welfare, freedom and happiness of every person in Ghana and to provide adequate means of livelihood and suitable employment and public assistance to the needy ${ }^{68}$

In this context, history is one of the school lessons that teach students to be modern.

Discussing modernisation, history textbooks explained that western colonisation in Ghana was a necessary step. Throughout the colonial period Ghanaians knew western education, which taught them about reading, writing and arithmetic and transformed them into westernised persons. The history textbook for Junior Secondary education mainly

\footnotetext{
${ }^{63}$ One of the studies is Kumaran Rajandran, 'Us and Them: The Portrayal of Malaysians and British in Malaysian History Textbooks', Journal of Asian and African Studies 48, no. 3 (2012): 320.

${ }^{64}$ Noraini M. Noor, 'The Future of Malay-Chinese Relations in Malaysia', in Peace Psychology in Asia, ed. C. J. Montiel and N. M. Noor (New York: Springer Science+Business Media, 2009), 163.

${ }^{65}$ Sandra Khor Manickam, 'Textbooks and Nation Construction in Malaysia', Asia Pacific Research Forum 28 (2005): 80.

${ }^{66}$ Ibid., 81.

${ }^{67}$ Cheah Boon Kheng, 'Ethnicity, Politics, and History Textbook Controversies in Malaysia', American Asian Review 21, no. 4 (2003): 233.

${ }^{68} \mathrm{Article} 36$, clause 1 of the 1992 Constitution of the Republic of Ghana.
} 
focused on the westernised group of people, including biographies of three Ghanaians educated in England in the second of three chapters and a biography of Kwame Nkrumah in the last chapter. ${ }^{69}$ From this viewpoint, history textbooks presented western colonisation (Portuguese and then British) as positive for Ghanaians. The colonial power was positioned as a main factor in unifying, modernising, even civilising Ghana. ${ }^{70}$

To construct a stronger discourse, modernisation supporters negated the group who wanted to preserve indigenous culture as conservative. The group was described as keeping Ghana as an underdeveloped country by preserving old traditions such as early marriage, widowhood rites, female genital mutilation and the Trokosi system. ${ }^{71}$ Describing the negativeness of old traditions and the conservative was a way to produce a discourse proposing that modernisation was urgently needed. In alignment with the production of such a discourse, history textbooks of Ghana were also constructed to negate old traditions. Stagnation of economic growth, for example, was explained in history textbooks as a result of Ghana's perniciously high fertility rate that was rooted in traditional beliefs and customs. ${ }^{72}$

\section{Conclusion}

The proclamation of independence on 17 August 1945 did not mean that colonialism ended. When Suharto replaced Sukarno in 1966, the narrative of Indonesia as friendly towards the Western Bloc was strengthened in the history textbooks. The fundamental change occurred beginning with the 1975 curriculum as the narrative in new secondary history textbooks became more colonialist in perspective. Through mandatory textbooks published by the government, a new discourse was produced. Dutch colonialism and imperialism in Indonesia was no longer considered a cause of misery; instead, it became the conveyor of development. The economic policies at the end of the nineteenth century and the Ethical Policy in the 1900s were established as determinant factors for the emergence of Indonesian nationalism in 1908. The discourse that Dutch colonisation was the conveyor of Indonesian development was explored in history textbooks during the New Order era and later. However, the Indonesian people were positioned as the object of the Dutch policies and the nation's developments were seen as an unintended result.

\section{List of textbooks quoted}

Gregorius Moedjanto, Nani Sunarti, Chr. Kristanto Dh., Anton Haryono, and A.A. Padi, Sejarah Nasional Indonesia untuk SMA (National history of Indonesia for high school), vol. 3 (Yogyakarta: Gramedia Widiasarana, 1992).

\footnotetext{
${ }^{69}$ David Peterson Del Mar, 'A Pragmatic Tradition: The Past in Ghanaian Education', Africa Today 59, no. 2 (2012): 28.

${ }^{70}$ lbid., 30.

${ }^{71}$ Judith Bawa,'Strengthening Social Structures for Protecting Women's Rights Among the Kassena of Northen Ghana', Ghana Journal of Development Studies 9 (2012): 46-8. The Trokosi system is a religious and cultural practice of sexual slavery in Ghana where pre-teen and teenage girls are kept as unpaid servants and sex slaves by West African voodoo priests to pay for the sins of their families against traditional gods and spirits. See Amy Small Bilyeu, 'Trokosi - The Practice of Sexual Slavery in Ghana: Religious and Cultural Freedom vs. Human Rights', Indiana International \& Comparative Law Review 9, no. 2 (Indianapolis: Robert H. McKinney School of Law, 1999): 457.

${ }^{72}$ Del Mar, 'A Pragmatic Tradition', 29.
} 
I Wayan Badrika, Sejarah Nasional Indonesia dan Umum untuk SMA (National history of Indonesia and the world for high school), vol. 2 (Jakarta: Erlangga, 1997).

Nugroho Notosusanto and Yusmar Basri, eds., Sejarah Nasional Indonesia Untuk SMA (The national history of Indonesia for high school), vol. 3 (official textbook) (Jakarta: Departemen Pendidikan dan Kebudayaan, 1981).

Sardiman A.M. and Amurwani Dwi Lestariningsih, Sejarah Indonesia (History of Indonesia), vol. 4 (Jakarta: Departemen Pendidikan dan Kebudayaan, 2014).

Sardiman A.M. and Kusriyantinah, Sejarah Nasional dan Umum untuk SMA (National history of Indonesia and the world) (Surabaya: Kendang Sari, 1996).

Siti Waridah Q., Sukardi and Sunarto, Sejarah Nasional dan Umum untuk SMA (National history of Indonesia and the world), vol. 2 (Jakarta: Bumi Aksara, 2000).

Tarunasena M., Sejarah untuk SMA (History for high school), vol. 2 (Bandung: Armico, 2009).

\section{Disclosure statement}

No potential conflict of interest was reported by the author.

\section{Funding}

This work was supported by the Indonesian Directorate of Research and Community Service of the Ministry of Research, Technology and Higher Education [grant number 051/HB-LT/IV/2017].

\section{Notes on contributor}

Hieronymus Purwanta is an associate professor at Department of History Education, Faculty of Teacher \& Training Education, Sanata Dharma University, Yogyakarta, Indonesia. His research interest is discourse production and reproduction, especially the use of history as a tool of powerful groups in infusing a discourse or discourses into Indonesian young generations. 